\title{
MUJERES ENTRE REJAS: RESEÑA HISTÓRICA SOBRE PENAS Y RECLUSIÓN DE MUJERES EN EL PARAGUAY -DESDE LA COLONIA HASTA NUESTROS DÍAS-
}

WOMEN IN PRISON: HISTORICAL OVERVIEW ON PENALTIES AND IMPRISONMENT OF WOMEN IN PARAGUAY -FROM THE COLONY UNTIL OUR DAYS-

Mary Monte de López Moreira ${ }^{1}$

Enviado: 2/2/2021

Aceptado: $7 / 4 / 2021$

Resumen: Desde los originarios días de la conquista lusohispana en el Nuevo Mundo, tanto los hombres y las pocas mujeres que arribaron a estas tierras cometieron diversos tipos de transgresiones que fueron sancionadas con reclusiones y varias clases de castigos. Con el transcurrir de los años, no solo las europeas fueron sentenciadas, sino también las criollas, mestizas e indias. Durante el período colonial, a más de las infracciones comunes como los robos

${ }^{1}$ Academia Paraguaya de la Historia y CONACYT - Paraguay. Contacto: marymontelm@gmail.com 
- el desacato a las autoridades, se condenaban la hechicería, prostitución, adulterio y concubinato. Las mujeres que transgredían estos dos últimos, eran castigadas con más severidad que los hombres inculpados en el mismo delito. En los primeros años de vida independiente, los gobiernos siguieron aplicando las antiguas Leyes medievales e inclusive con más rigor cuando se trataba de traición a la patria. Recién a partir de 1870, se introdujeron normativas más modernas y se promulgaron nuevos Códigos Penales. En el transcurso del siglo XX, otra clase de faltas se sumaron a las ya mencionadas, como el tráfico y consumo de drogas no autorizadas y, en los últimos años, varias mujeres se vieron implicadas en actividades delictivas como secuestros y ataques terroristas. La presente investigación intenta aportar a la Historia Social un capítulo poco estudiado sobre la reclusión de mujeres en el Paraguay.

Palabras clave: mujeres; prisión; reclusión; penas; castigos; condenas.

Abstract: From the originating days of it conquers lusohispana in the new world, both of them men and them few women that arrived at these lands committed various types of long. that were sanctioned with detentions and several kinds of punishment. With the passing of the years, not only the European were sentenced, but also the Creole, mestizo and Indian. During the period colonial, to more than them transgressions common as the killings, robberies, disrespect to the authorities, is condemned it wizardry, prostitution, adultery and concubinage. The women that violated these two recent were punished with more severity that those men, 
accused in the same crime. In the first years of independent life, Governments followed by applying the ancient medieval laws and even with more rigors when it was treason to the homeland. Newly starting from 1870, is introduced regulatory more modern and has enacted new codes criminal. In the course of the century XX, another class of failures is added to them already mentioned as the traffic and consumption of drugs not authorized and, in them last years, several women are looked at involved in activities criminal as kidnappings and attacks terrorist. The present research tries to bring to the Social History a chapter little studied on the confinement of women in Paraguay.

Keywords: women; prison; detention; punishment; punishment convictions. 


\section{Introducción}

El estudio sobre mujeres en la actualidad, no solo enfoca temas nuevos, sino que impone también una reconsideración crítica de las premisas y criterios de la obra académica existente. La inclusión del tema mujer en la historia social de cada nación implica, necesariamente, la redefinición y desarrollo de nociones tradicionales del significado histórico, de modo que abarque experiencias de casos personales y actividades públicas o privadas.

Los escasos antecedentes sobre el tema propuesto fueron motivo suficiente para reseñar la intrusión femenina en el ámbito punitivo en el transcurso de los distintos períodos históricos del Paraguay y, construir con ello, un capítulo diferente de la historia social que proporcionará nuevas perspectivas a antiguos problemas subyacentes en casi todos los pueblos de América Latina, pues Asunción, al igual que en otras villas fundadas en los años iniciales de la conquista luso-hispana en el Nuevo Mundo, no contó con un edificio distintivo que sirviera de reclusorio para albergar a las mujeres delincuentes. En cumplimiento de las Leyes españolas, hubo intenciones de construir una cárcel para hombres y otra para mujeres, pero la precariedad económica y el poco interés que la corona demostró por la provincia paraguaya a causa de la inexistencia de metales preciosos, impidieron la realización de tales propósitos.

Las Leyes de Indias, promulgadas en 1680, a más de sancionar los homicidios, robos y traición al gobierno, condenaban la prostitución, el adulterio, las uniones libres y la hechicería, con penas carcelarias y/ o castigos corporales 
como los azotes y la reclusión con grilletes ${ }^{2}$, grillos ${ }^{3}$ y cepos. En los casos de adulterio y concubinato, la aplicación de las sentencias era más severa para las mujeres que para los hombres.

En las primeras décadas del período independiente, los gobiernos unipersonales de Gaspar Rodríguez de Francia (1814-1840), de Carlos Antonio López (1841-1862) y de Francisco Solano López (1862-1870), merecen especial atención por la peculiaridad de los casos y, si bien, para ese tiempo, ya tendrían que haberse derogado las Leyes españolas, estas siguieron vigentes y a veces con más rigor que durante la colonia. Se mantuvieron códigos medievales que no distinguían la moral del derecho, el fuero civil del religioso, lo público de lo privado y que sancionaban la tortura, el destierro, la confiscación de bienes, la pena de muerte por razones políticas y distintos tipos de 17 discriminación étnica. Recién en 1870, después de la Guerra contra la Triple Alianza, se promulgó una Carta Magna de carácter liberal y se introdujeron algunas teorías jurídicas más modernas.

En las etapas posteriores y durante las dictaduras militares del siglo $\mathrm{XX}$, no solo fueron detenidas y encarceladas las mujeres que infringían delitos comunes, sino también aquellas opositoras a los citados regímenes. A partir de la década de 1880, otros tipos de transgresiones se sumaron a los ya mencionados como: el tráfico de estupefacientes que hasta el día de hoy sigue involucrando a centenares de mujeres. En los últimos años, varias de ellas, se vieron implicadas en actividades delictivas que anteriormente eran

${ }^{2}$ Collar de hierro que servía para asegurar la cadena incrustada en la pared o a una viga.

${ }^{3}$ Conjunto de dos grilletes que se colocaban en los pies de los presos. 
perpetradas solo por hombres, como secuestros, asaltos a camiones de caudales y ataques terroristas.

Como el tema casi no ha sido tratado por otros especialistas, el presente trabajo se convierte en un conciso aporte que intenta dar una visión holística del sistema carcelario para mujeres en el Paraguay, desde los inicios de la conquista española en el antiguo territorio paraguayo hasta nuestros días, y, al mismo tiempo, incorporar al debate historiográfico un planteo que cuestiona la inequidad de género en cuanto a reclusiones, penas y castigos en el transcurso de los distintos procesos históricos paraguayos.

\section{Periodo Colonial}

La primigenia casa-fuerte de Nuestra Señora de la Asunción, erigida en 1537, careció de un recinto carcelario para recluir a personas transgresoras de las leyes establecidas por la corona. Ni aun cuando, en 1541, el emperador Carlos $\mathrm{V}$ confirió al citado reducto la categoría de ciudad, con el establecimiento del cabildo y su correspondiente escudo de armas, se pensó en la instalación de una cárcel. En ese mismo año, la población europea aglutinada en la comarca asuncena aumentó considerablemente, por decisión del primer gobernador, Domingo Martínez de Irala, quien resolvió deshabitar el primitivo fuerte de Buenos Aires ${ }^{4}$, debido a la hostilidad de los indígenas de la región, y por el deseo de concentrar en

\footnotetext{
${ }^{4}$ La región del estuario del Plata fue explorada por varias brigadas al servicio de España pero, ninguna de ellas tomó dominio ni estableció población permanente. La conquista del territorio se inició a partir de 1536 con la hueste que arribó en la armada del primer adelantado Pedro de Mendoza, quien a poco de llegar fundó el fuerte de Nuestra Señora del Buen Aire.
} 
un sólo lugar -más seguro- bajo las órdenes de un sólo capitán general, a todos los habitantes españoles del Río de la Plata. Unos trescientos cincuenta hombres ${ }^{5}$ y las mujeres que no regresaron a España con el adelantado ${ }^{6}$, por ser esposas, hijas 0 criadas de los conquistadores, constituyeron la inicial población europea instalada en Asunción?

La etapa de conquista no fue fácil en el antiguo territorio paraguayo, ocupado en su región oriental, por nativos de la familia lingüística guaraní, de cultura neolítica, y la occidental habitada por varias etnias paleolíticas. Someter a tales grupos aborígenes presentó una serie de dificultades para los españoles, quienes impulsados por sus propias ambiciones de encontrar metales preciosos, infringían constantemente las órdenes gubernamentales 0 se rebelaban contra las autoridades. A ese efecto, recién en enero de 1545, los alcaldes del cabildo, en una sesión abierta de la citada corporación, en donde también participaron los pobladores, se resolvió construir un penal que albergase a tales proscritos de la ley. Con ese propósito se otorgó una carta de obligación al escribano Martín de Orué para que viajase a la metrópoli y presentara al rey una serie de peticiones, entre las que se mencionaban la

${ }^{5}$ Gandía, Enrique. 1932. Historia de la conquista del Río de la Plata y del Paraguay. Buenos Aires. Librería de A. García Santos, p. 89.

${ }^{6}$ El adelantado Mendoza, por motivos de salud regresó a España, falleciendo en el viaje de retorno.

${ }^{7}$ No existen referencias acerca de cuantas mujeres españolas quedaron en el Río de la Plata en el tiempo de la despoblación de Buenos Aires. Es muy probable que hayan sido unas diez y ocho o diez y nueve. Los historiadores que escribieron sobre la conquista del territorio no las mencionan. Los datos hemos obtenido de Catálogo de pasajeros a Indias. 1942. Vol. II y III. Editorial de la Gavidia. Sevilla. 
construcción de un edificio que sería sede del cabildo y una cárcel pública ${ }^{8}$.

Sin demoras, el monarca otorgó la licencia para la edificación de ambas obras, pero una década más tarde, el cabildo aún seguía sin contar con su local propio. Las sesiones se efectuaban en la vivienda que había pertenecido al primer gobernador de la provincia, don Domingo Martínez de Irala, fallecido en 1556, en donde una de las dependencias con cerrojos oficiaba de penitenciaría con nueve grillos de hierro y dos cepos de madera con sus llaves y candados ${ }^{9}$.

En ese acaecer, durante el reinado de Felipe II (1556-1598), se dictaron, para todas las provincias americanas, disposiciones relativas al establecimiento de presidios, penitenciarías, casas de disciplina, ergástulas y varios tipos de prisiones "para custodia y guarda de los delincuentes y otros que deben estar presos...sin costa de nuestra Real Hacienda". Con respecto a la organización carcelaria, las leyes disponían que debieran constituirse cárceles para varones y reclusorios exclusivos para mujeres, separadas e incomunicadas de aquellos, y donde deberían "guardar toda honestidad y recato". Las cárceles, tanto para hombres como para mujeres debían contar con un capellán para oficiar las misas dominicales y visitar a los presos los días hábiles para confesión. Esta reglamentación fue ratificada por los sucesores del citado monarca y difundida más tarde, por las Leyes de Indias ${ }^{10}$.

\footnotetext{
${ }^{8}$ ANA. SNE. Vol. 302. Fo. 21. 25-I-1545.

${ }^{9}$ Durán, Margarita. La cárcel pública de Asunción (1541-1955). Diario ABC Color. 19-VIII-2012.

${ }^{10}$ Recopilación de Leyes de los Reynos de las Indias. Libro VII. Leyes I, II, III. Titulo

6. Tomo Segundo. Cuarta Impresión. Madrid, 1943. Consejo de la Hispanidad. La
} 
Las Partidas de Alfonso $\mathrm{X}$, la legislación conciliar y el Derecho Consuetudinario se constituyeron en el núcleo jurídico fundamental de la nueva legislación indiana, con algunas pequeñas modificaciones introducidas en Recopilación de Leyes de los Reinos de Indias de 1680. De ahí que los Tribunales americanos condenaban la tortura, los azotes, el destierro, la confiscación de bienes y la pena de muerte por razones políticas. Esta legislación, siguió en vigor en toda América hispánica durante el periodo colonial. Dicho cuerpo jurídico discriminaba, además, los distintos tipos de personas de acuerdo con su origen étnico. Generalmente, las penas para los indígenas, negros y mestizos eran más severas que las aplicadas a los blancos criollos o europeos.

La precariedad económica existente en la provincia del Paraguay no permitió que las leyes se pudieran cumplir con 21 el debido rigor, pues, a fines del siglo XVI, un mismo edificio acogía, tanto a presos varones como las mujeres. Estas últimas se hallaban agrupadas en una pequeña habitación contigua a las demás celdas. Por la insalubridad del ambiente y por la escasez alimentaria, continuamente las reclusas solicitaban a las autoridades el cumplimiento de sus penas en sus propias viviendas. Tal el caso de Marina Lucero, encarcelada desde hacía varios años, acusada del asesinato de su esposo, Bartolomé Cobos.

En un petitorio dirigido al teniente de gobernador, Alonso de Vera y Aragón, en vísperas de la Navidad de 1588 y refrendado por el escribano del gobierno; Marina Lucero se declaraba inocente, alegando que el verdadero culpable se encontraba libre mientras ella debía purgar una pena injusta.

Recopilación de Leyes de los Reynos de Indias fue sancionada por el rey Carlos II el 18de mayo de 1680. Consta de 9 Libros con 218 títulos y 6.377 Leyes. 
El documento rezaba cuanto sigue: "que vuestra merced me mande mudar la carcelaria que tengo conmutándomela en mi chacra porque aquí recibo notorio agravio y paso mucha necesidad por ser pobre y estar cargada de hijos como a vuestra merced costa. Por tanto a vuestra merced pido $y$ suplico ansí lo provea y mande pues justicia la cual pido y en lo necesario"11.

El gobernador, probablemente, movido más por sus sentimientos religiosos que por las ingrata situación de la mujer, le otorgó la reclusión domiciliaria, pero no en su chacra, como Lucero había solicitado, sino en casa del aguacil, manifestando que atento a lo cual y en reverencia del glorioso nacimiento de nuestro salvador Jesucristo dijo que le removía y removió la carcelaria y prisión, ordenando que dicha autoridad policial se hiciese cargo de la procesada, notificándole que no debía ausentarse ni quebrantar las disposiciones sobre su prisión, so pena de muerte ${ }^{12}$. La concesión efectuada por Vera y Aragón, con los años se convirtió en costumbre, es decir el gobernador de la provincia, el día de la Navidad concedía la libertad a unos o más presos que habían demostrado buena conducta.

Casos similares al de Marina Lucero eran muy frecuentes, no solo en el Paraguay, sino en toda Hispanoamérica. Muchas mujeres eran inculpadas por diversos delitos de acuerdo con la legislación vigente en el Nuevo Mundo. Es así como las citadas Leyes penalizaban con bastante rigor el adulterio, la prostitución y la hechicería, transgresiones que preocupaban tanto a las autoridades civiles, como a las religiosas. Por ejemplo, en Lima del siglo XVII, las denuncias por adulterio eran procesadas de manera específica en la Real Audiencia.

\footnotetext{
${ }^{11}$ ANA. Copias de Actas del Cabildo de Asunción. Vol. 11. 24-XII-1588, pp. 129/130.

12 Ibídem, p.131.
} 
No obstante, los castigos para los hombres eran diferentes que para las mujeres. A los primeros se les imponían penas económicas o el destierro, mientras que las mujeres adulteras, además de tener que pagar las multas asignadas, debían someterse a sanciones difamantes, tales como la pérdida de su vestuario, corte de cabello o pasear por las calles de la ciudad con un cartel en el cuello, exponiendo públicamente su pecado. La penalización del adulterio femenino, permitía al marido dar muerte a los culpables o entregarlos a la justicia.

En contrapartida, el adulterio masculino fue escasamente considerado en la sociedad colonial hispanoamericana y, por consiguiente, los expedientes de la época aparecían rotulados con la inscripción de "mancebía de hombres casados". Es decir que, en el adulterio cometido por un hombre casado, la manceba era quien jugaba el rol más pecaminoso y quien debía recibir las penas más graves, inclusive la cárcel. Para 23 las autoridades eclesiásticas, el adulterio cometido por una mujer era "pecado mortal gravísimo contra la caridad y la justicia"13. En definitiva, en toda Hispanoamérica, el adulterio de la mujer era un delito grave, no así el del hombre.

A la mujer adúltera se le imponían las penas más crueles, como los ya citados castigos, que a veces incluían, también, la muerte, mientras que para los varones, las sanciones eran más leves. Está claro que la legislación sobre delitos sexuales trató con más severidad a las mujeres que a los hombres y, de acuerdo con derecho en vigor, se infiere que el adulterio era fundamentalmente un crimen femenino ${ }^{14}$.

\footnotetext{
${ }^{13}$ Mannarelli, María Emma. 1993. Pecados púbicos. La llegitimidad en Lima, siglo XVII. Lima, Editorial Flora Tristán, pp. 133/135

${ }^{14}$ De las Heras Santos, José Luis. 2016. La mujer y la moral en la legislación castellana de la Edad Moderna. www.historiaetius. Documento 30, p. 6.
} 
En el Paraguay, partir de 1560, ya se declararon ilícitas las uniones libres. Españoles, mestizos e indios eran encarcelados o pagaban multas, si vivían en concubinato, y peor aún si eran descubiertos en adulterio.

Tanto el hombre como la mujer tenían el derecho de solicitar el divorcio por motivos de adulterio, pero el derecho común y real se concedía solo al esposo. En el Paraguay, en los primeros años coloniales, se dio esta misma modalidad y los asuntos de esta naturaleza se presentaban al cabildo con la presencia del gobernador de la provincia, del fiscal y del juez. Un caso peculiar fue el de Beatriz Hernández, que en 1584, denunció a su marido Diego Bañuelos, por los maltratos físicos que éste le había propinado en la vía pública, frente a los vecinos. El fiscal de la causa presentó el pleito al gobernador, Juan de Torres Navarrete, quien ordenó que el hombre pagase "buenas fianzas legas llanas e abonadas y que tratara bien a la dicha Beatriz Hernández su mujer e no la castigara ni matara, ni herirla por esta razón ni otra indirecta e que si la dicha mujer cometiere algún delito o culpa que pidiera contra ella a quien y con derecho deba su justicia"15.

Ante esta sentencia, el inculpado abonó 30 varas ${ }^{16}$ de lienzo al juez y al escribano, 50 varas del mismo material, siendo así redimido inmediatamente de su pena. Tras su liberación, el mencionado Bañuelos, alegó que tenía todo el derecho de castigar a su mujer porque esta había cometido adulterio con un tal Juan Espinoza y por ese motivo en el mismo acto, presentaba una querella en contra de ambos.

\footnotetext{
${ }^{15}$ ANA. Sección Civil y Judicial. Vol. 1676. 26-VI-1584. Fos. 1-53.

${ }^{16}$ Unidad de longitud equivalente aproximadamente a $84 \mathrm{~cm}$.
} 
Durante el proceso, que duró varios meses con la presencia de diversos testigos ${ }^{17}$, se puede advertir la parcialidad de las autoridades en el juzgamiento del caso, privilegiando más al esposo, quien también cometió el mismo delito y no una vez, sino en reiteradas oportunidades, según lo testimoniado por una de las declarantes, que trató de justificar a la acusada, alegando que el adulterio cometido por la Hernández era por represalias hacia Bañuelos, pues era "de notoria pública su fornicación con Ana Jiménez y otras mujeres" y que en una ocasión, la inculpada, cegada por los celos, se había enfrentado con la mencionada vecina. Dicho testimonio fue corroborado por varias indígenas, testigos presenciales de las infidelidades del querellante, pero el juez y el escribano hicieron caso omiso de dicho argumento, basándose probablemente en el veredicto de los juristas y teólogos de la época, quienes sostenían que cuando "el desposado comete fornicación no es adulterio ni circunstancia que se deba confesar"18.

Concluido el juicio, Juan Espinoza debió pagar por su libertad unas cuantas varas de lienzo y a Beatriz Hernández se le impuso una fuerte multa, pero como la mujer carecía de bienes, ya que el esposo era el depositario de su dote, esta tuvo que cumplir su pena carcelaria en casa de "un vecino respetable, don Simón Jaques"19, a más de sobrellevar el infortunio de ser una mujer divorciada por motivo de adulterio.

Recién, en los primeros años del siglo XVII, el cabildo de Asunción contó con un edificio exclusivo para sus fines

\footnotetext{
17 El documento menciona como testigos tanto a hombres como a mujeres de diversas condiciones socio-culturales.

${ }^{18}$ Machado de Chávez. El Perfecto II, p. 429. Citado por Mannarelli, María Emma. 1993. Pecados púbicos, p.134.

${ }^{19}$ ANA. Sección Civil y Judicial. Vol. 1853. 7-XII- 1584. Fos. 1-95.
} 
municipales y se construyó la cárcel pública. Ambos inmuebles, aledaños a la casa episcopal y a la de gobierno, se erigían en torno a la plaza mayor, con vista al río Paraguay. La primera cárcel pública contó con cuatro calabozos, dos de ellos albergaban a presos de baja condición socio-económica, uno destinado a "sujetos de distinción y el otro lo ocupan mujeres que se prenden". En esta última celda se oficiaba la misa dominguera ${ }^{20}$.

En cuanto a los casos de prostitución, esta actividad era considerada como una acción corruptora para la sociedad: "un mal que afecta a los hombres y mujeres honestas". Generalmente, las mujeres dedicadas a este menester no iban a la cárcel pública, sino más bien eran condenadas al exilio de su comunidad, so pena de ser castigadas públicamente "con azotes" si regresaban al pueblo o eran sorprendidas cometiendo el mismo ilícito.

Las leyes contra el adulterio, amancebamiento y prostitución tuvieron vigencia en toda la vida colonial paraguaya $y$, si bien se difundían a través de bandos y decretos con la advertencia de penas carcelarias o de azotes públicos, especialmente para las mujeres, su aplicación en la práctica fue menos estricta ${ }^{21}$, pues los casos de uniones libres fueron muy comunes en esta época y en las siguientes. Al respecto, se pueden inferir, a la luz de la documentación existente, dos factores importantes: que la relación no debía

\footnotetext{
${ }^{20}$ Durán, Margarita. La cárcel pública de Asunción... opus cit.

${ }^{21}$ Un bando promulgado por el gobernador Pedro Melo de Portugal en 1778 expresaba lo siguiente: "Que nadie se atreva a estar amancebado y sea alcahuete o consentidor de tan enorme y escandaloso pecado; y los que los hicieren, o estuvieren, se notifiquen de tal comunicación ilícita, pena que se procederá con todo rigor al castigo conveniente, con solo breve Sumaria y averiguación, para cuyo efecto les amonesto, cito y apercibo...". Caballero Campos, Herib. 2007. Los bandos del buen gobierno de la Provincia del Paraguay 1778-1811. Asunción, p. 28-30.
} 
ser muy evidente y que la mujer debía ser fiel a esa unión y aunque las amistades ilícitas eran siempre conocidas entre los familiares y vecinos, era fundamental no demostrarlas en público $^{22}$. Estas uniones de hecho no tenían penas carcelarias o de proscripción y menos aún si la mujer quedaba embarazada. No así, los adulterios que también, eran muy frecuentes.

Con vasta procacidad y sin perjuicio de disolución conyugal, los hombres de todas las condiciones sociales se relacionaban con mujeres fuera de su matrimonio, amparados en la legislación que favorecía más a hombres que a mujeres, pues por este delito, ellas -no los adúlteroseran penadas con la reclusión o el destierro, en salvaguarda "de las buenas costumbres". Tal el caso de María Ana Gómez, del pueblo de Pirayú, quien por mantener relaciones con un reputado comerciante casado, fue recluida en la casa 27 de doña Luisa Simbrón en donde "volvió a ejercitar su vida desarreglada en ofensa a Dios"23. Por ese motivo, la mujer fue trasladada al domicilio del Alférez Pablo de los Ríos y, allí mantuvo relaciones íntimas con un esclavo casado del militar, razón por la cual fue expulsada de dicha vivienda, y el juez dictaminó su destierro de la localidad. Sin embargo, María Ana apeló a la resolución alegando que tales injurias eran falsas. Luego de una investigación y con la presencia de varios testigos que certificaron su buen comportamiento, el gobernador concedió tal petición enviándola confinada a una casa de "familia decente" e instándola a que no volviese

22 Potthast-Jutkeit, Bárbara. 1996. Paraíso de Mahoma o País de las Mujeres. Asunción. Instituto Cultural Paraguayo-Alemán, p. 177.

${ }^{23}$ A.N.A. S.H. Vol. 203. N N 3 Fo. 7. 29-I-1807. 
a reincidir en actos que atentaban contra la moral y las buenas costumbres ${ }^{24}$.

Casos similares eran muy corrientes en la sociedad paraguaya y, como los pueblos carecían de reclusorios para mujeres, estas eran encarceladas en casas de vecinos respetables 0 deportadas a otras comunidades. No obstante, las mujeres que delinquían en robos o asesinatos eran destinadas a la cárcel pública de la capital.

En el transcurso de todo el periodo colonial, las mujeres detenidas por diversos delitos siguieron ocupando el mismo recinto donde se alojaban los presos varones. Estaban separados, a veces, por una endeble cerca que no impedía el contacto entre ellos. Empero, los últimos gobernadores provinciales trataron de paliar esta circunstancia y dar cumplimiento a las Leyes de Indias proyectando establecer reclusorios separados para hombres y mujeres, pero sin resultados positivos. Recién en 1793, el cabildo asunceno resolvió construir una cárcel para mujeres, que constaría de dos habitaciones con sus respectivas puertas y ventanas. En la más amplia se alojarían a las señoras de cierto rango social y en la más pequeña a las demás delincuentes, es decir a las ladronas y asesinas ${ }^{25}$. Es probable que en la primera, estuviesen las que habían delinquido con el crimen de adulterio o con alguna otra transgresión, pero por su condición socioeconómica se hallarían separadas de las presas comunes.

\footnotetext{
${ }^{24}$ Ibídem. Fo. 8.

${ }^{25}$ ANA. Colección copias de Actas del Cabildo de Asunción. Vol. 31. 7-I-1793.
} 


\section{Periodo Independiente}

Con la independencia del Paraguay en 1811, no variaron en demasía las costumbres de la sociedad colonial en lo relativo a las uniones libres, adulterios y delitos de diversas clases, cometidos por hombres y mujeres. Para comprender mejor las peculiaridades de la época, conviene mencionar que en el Paraguay, recién en 1870 se promulgó la primera Constitución con las características jurídicas inherentes a toda Carta Magna moderna $y$, por consiguiente, en el transcurso de los primeros gobiernos independientes y vitalicios de Rodríguez de Francia y los dos López, rigieron las antiguas leyes coloniales concebidas en el Medioevo castellano. Estas Leyes desconocían la distinción moderna entre moral y derecho, entre el fuero civil y religioso, entre lo público y lo privado y concedían a los funcionarios públicos

29 el poder de fiscalizar la vida privada de cada vecino ${ }^{26}$.

\section{La dictadura francista}

El primer gobierno independiente lo asumió la Junta Superior Gubernativa (1811-1813), con cinco miembros, unos de los cuales era el doctor Francia. Posteriormente advino el Consulado (1813-1814), con Fulgencio Yegros y Francia, nuevamente, y a continuación la Dictadura, primero la temporal (1814-1816), y luego la perpetua (1816-1840). Durante el transcurso de las casi tres décadas de su gobierno, imperó la legislación española que prohibía “...los vicios y desórdenes públicos, principalmente los que puedan ser causa de ruinas espirituales y temporales de los otros,

26 Rodríguez Alcalá, Guido. 1997. Justicia Penal de Francia. Asunción. RP Ediciones, p.26 
como los escándalos y amancebamientos públicos, robos y fuerza de bienes o de mujer (...) así como el cuidar la observancia de la buenas costumbres cristianas, civiles y morales..." Además, se recomendaba delatar a los vecinos que infringían tales ordenanzas ${ }^{27}$.

A más de lo señalado, hubo también otras restricciones, como la dictada por Francia el $1^{\circ}$ de julio de 1814, durante el gobierno consular, mediante el cual se prohibía el "matrimonio de varón europeo con mujer americana conocida y reputada por española en el pueblo desde la primera hasta la última clase del Estado, por ínfima y baja que sea, so pena de extrañamiento y confiscación de bienes de los párrocos o curas autorizantes de tal matrimonio; y de confinamiento en el Fuerte Borbón del europeo contrayente por diez años y confiscación de sus bienes ${ }^{28}$.

Con esta medida el doctor Francia pretendía asegurar que los antiguos dueños del poder político, social y económico del Paraguay, en el futuro no tuvieran la más mínima oportunidad de alcanzar su posición dominante anterior. A modo de ejemplo, una fuente documental de 1816 constata la tentativa de Juan Bautista Carísimo, de casarse con una paraguaya en Villarrica. Al enterarse Francia de esta circunstancia por medio del alcalde del cabildo de aquella ciudad, ordenó la prisión del sacerdote oficiante y de los implicados "...por la enorme criminalidad del clérigo Valle $y$ sus cómplices..." refiriéndose al contrayente, al padre de éste, el español, don José Carísimo y al padrino, otro europeo, don Domingo Mereque "por rebeldes $y$ desobedientes...". Todos fueron remitidos a la cárcel de

${ }^{27}$ ANA. SJC. Vol. 1670. Año 1819.

${ }^{28}$ Potthast-Jutkeit, Bárbara. 1996 Paraíso de Mahoma... opus cit., p.69. 
Asunción y sus bienes y derechos fueron confiscados ${ }^{29}$. Con relación a la novia, como ocurría en todos los casos, se la enviaba a una "casa de vecinos respetables" para que en el futuro no intentase reincidir en el "pecaminoso crimen" de contraer nupcias con extranjeros.

Por ese tiempo, el Dictador ordenó la demolición del antiguo edificio del cabildo, con la intención de construir un nuevo inmueble $y$, en consecuencia, algunos presos políticos fueron trasladados al Cuartel de Caballería, mientras durase la obra. A los demás reclusos se los condujo a una residencia particular perteneciente al regidor de dicha corporación. La misma constaba de cuatro habitaciones, tres para los hombres y la cuarta destinada a las mujeres. Alrededor de dicho inmueble se construyó una valla de palmas para impedir el contacto con la gente de afuera ${ }^{30}$. Con esta medida, los presos de ambos sexos volvieron a 31 ocupar el mismo local destinado a la cárcel pública. Una vez concluida la nueva edificación capitular, los presos no retornaron al cabildo, ellos permanecieron en la casa arrendada, y los detenidos políticos continuaron en el citado reducto de Caballería.

Una interesante descripción de la cárcel nos brindan los dos médicos suizos, Johan Rengger y Marcéli Lompchamp, que vivieron en el Paraguay desde julio de 1819 hasta mayo de 1825. Los profesionales remontaron el río Paraná desde Buenos Aires hasta Asunción con el propósito de investigar la fauna y flora paraguayas. Los resultados se plasmarían

\footnotetext{
${ }^{29}$ A.N.A. S.N.E. Vol. 750. 23-X-1816.

${ }^{30}$ Durán, Margarita. La cárcel pública opus cit.
} 
posteriormente en una obra sobre historia natural del Río de la Plata ${ }^{31}$.

Durante los años de su estadía en el país, ambos médicos, en repetidas oportunidades, fueron requeridos por funcionarios del gobierno para socorrer a los detenidos que se encontraban enfermos. De acuerdo con sus relatos, se infiere que en tiempos de la dictadura existían dos tipos de cárceles: la del Estado y la pública. En la primera se alojaban a los presos políticos que habían atentado con acciones o palabras contra el régimen dictatorial, entre ellos muchos próceres de la Independencia. Estas prisiones estaban ubicadas en los diferentes cuarteles y consistían en pequeñas celdas sin ventanas o en subterráneos húmedos, y en donde las visitas de familiares o inclusive de los citados especialistas, estaban prohibidas. Estos prisioneros vivían incomunicados de por vida. En dichos reclusorios no se menciona la presencia de mujeres.

En la pública, la situación de los convictos no era más halagüeña que la anterior. Rengger relata en su crónica que "Allí se ven mezclados el indio y el mulato, el blanco y el negro, el amo y el esclavo; allí están confundidos todos los rangos, todas las edades, el delincuente y el inocente, el condenado y el acusado, el ladrón público y el deudor, en fin el asesino y el patriota y muy a menudo están sujetos a una misma cadena”. Con respecto a las mujeres, expresa que eran muy pocas las arrestadas. Ellas se encontraban recluidas en una celda que daba a un pequeño patio cercado por empalizadas y desde donde podían comunicarse con los demás detenidos y detalla que

${ }^{31}$ Rengger, J. -Lompchamp, M. 1828. Ensayo histórico sobre la Revolución del Paraguay y el Gobierno Dictatorial del Dr. Francia. París. Imprenta de Morteau, p, IX. 
"algunas mujeres de cierto rango, que se habian atraído el odio del Dictador, se vieron mezcladas allí con prostitutas y criminales, y expuestas a todos los insultos de los hombres. Llevan los grillos como estos, y ni aún la preñez alivia su condición"32.

Después de 1820, la condición de varios miembros de la élite criolla se agravó debido a la conspiración que se pretendía perpetrar contra de la vida del Dictador. El complot fue descubierto y el doctor Francia sometió a prisión a varios líderes que protagonizaron la gesta emancipadora, "en calidad de reos de alta traición, que con alevosía y asesinato intentaron conspirar contra el gobierno". Así la cárcel pública se llenó de detenidos, razón por la que el edificio fue ampliado con la incorporación de dos celdas, ubicadas en la casa colindante a la anterior y también arrendada de otro vecino. Los nuevos calabozos sirvieron para albergar a la 33 enorme cantidad de presos que constantemente eran demorados para averiguación o inculpados de haber participado en la citada conjuración. Varios españoles, igualmente, ocuparon tales dependencias por haberse negado a proveer las "donaciones voluntarias" que los extranjeros debían entregar al gobierno, so pena de prisión o fusilamientos ${ }^{33}$.

Pese a todas estas detenciones, es de admitir que el Dictador demostró bastante indulgencia en cuanto a las condenas y sentencias impuestas a las mujeres, frente a las asignadas a los hombres. Tal el caso de la parda María Valentina Robledo que había cometido un doble homicidio contra los que abusaron y asesinaron a su hija adolescente.

\footnotetext{
32 Ibídem, pp. 203/204.

${ }^{33}$ Monte de López Moreira, Mary. 2013. Pancha Garmendia. Asunción. El Lector, p. 24.
} 
El Dictador le conmutó la pena de azotes y la confinó en calidad de cocinera a la población de Tevegó ${ }^{34}$. Otras inculpadas y penadas a muerte tuvieron la misma suerte al conmutárseles sus condenas por las de "destierro perpetuo" de sus pueblos. Así fue el caso de la parda Isabel Tullo, quien en complicidad con una india asesinó a su pareja, José Aubá en Ñeembucú. Ambas se vieron beneficiadas con el confinamiento ${ }^{35} \mathrm{y}$, probablemente, no se las condenó a muerte porque el citado difunto era un europeo, ya que para ese entonces, los extranjeros, y más aún los españoles, eran considerados enemigos de la República.

Habitualmente, las penas de muerte, el cepo 0 el encarcelamiento por largos años, se imponían a los que "conspiraban contra el gobierno", fuesen estos criollos o extranjeros. Los castigos de azote se aplicaban a los salteadores, a los que cometían abigeato y a las prostitutas. Sin embargo, algunos hombres que violentaban o asesinaban a sus mujeres, eran condenados a muerte o penados de por vida con el cepo, como Jerónimo Vargas condenado al grillete hasta su muerte por causa de haber violentado a su mujer y causándole la muerte. En cambio, María Domínguez, homicida de su esposo, por alegar que su marido la maltrataba constantemente y más aún cuando éste se hallaba en estado etílico, se le impuso la pena de llevar grillos y fue recluida en su propio domicilio. No obstante, en breve tiempo por su ancianidad y delicadeza de salud "se les sacaron los grillos"36.

\footnotetext{
${ }^{34}$ La población de Tevegó era una localidad de mulatos libres.

${ }^{35}$ ANA. S.H. Vol. 226. 1--III-1816.

${ }^{36}$ Viola, Alfredo. 1983. Las cárceles en la época dictatorial. Asunción. Anuario del Instituto de Investigaciones Históricas "Dr. José Gaspar Rodríguez de Francia”. Año X. № X, pp.136/138.
} 
Otra inculpada, acusada de incendiaria, recuperó su libertad en poco tiempo por hallarse enferma "del morbo perlático". Del mismo modo, una joven mestiza que había cometido un homicidio de manera accidental fue puesta en custodia en casa de un sujeto de probidad ${ }^{\beta 7}$.

Con respecto a las relaciones ilícitas, el gobierno dictatorial seguía manteniendo en vigor las antiguas leyes españolas sobre la prohibición para blancos e indios de casarse con personas de piel negra. Situación que alentó las uniones ilegítimas entre indios y pardas y viceversa, e inclusive entre los mismos blancos, además de las extensión del concubinato en la clase alta. La mayoría de las familias acomodadas, de origen español o criollo, trataba de vivir en sus haciendas del interior, lo más discretamente posible y sin despertar la desconfianza del Dictador; más aún si un pariente había sido considerado traidor a la patria.

En esa coyuntura socio-jurídica, se continuó con las uniones de parejas entre los miembros de todas las clases, pero ya no sancionadas con alianzas legales -que en ese tiempo, solo la religiosa, era la permitida-, circunstancia favorecida por el decreto promulgado el 20 de setiembre de 1824 que establecía que "en el futuro todos los matrimonios celebrados sin autorización del Dictador serían nulos". Al concluir la década de 1820, se puede comprobar que habían proliferado en demasía los nacimientos, fuera de matrimonios formalmente constituidos, tanto en los estratos bajos, como en la clase de la antigua élite. El número de hijos ilegítimos en Asunción ascendió considerablemente, llegando a un $50 \%$ al final del citado período. En los últimos años de la Dictadura, esta cifra se acrecentó a un $80 \%$,

${ }^{37}$ Viola, Alfredo. 1983. Las cárceles. .. opus cit. p. 139. 
tanto en la capital como en las localidades del interior ${ }^{38}$, delitos que los delegados o jueces comisionados no pudieron penalizar.

De igual manera, sobre el tema de la prostitución, no se encuentran indicios claros acerca de la existencia de esta práctica como oficio, sino más bien se registran ciertos apelativos como "rameras, mujer pública, prostituta" conceptuando a las adúlteras o a mujeres que mantenían relaciones con más de un hombre. Pedro Rotela había cortado el cabello de su esposa, Ana Bargas porque había escuchado que esta le había sido infiel. Ante el juez de la causa, el marido la calificó de prostituta y recomendaba su encierro en la cárcel pública, hecho que no llegó a concretarse por la huida de la acusada a un pueblo del interior $^{39}$. En otros procesos semejantes aparecen las mismas denominaciones, precisando siempre la infidelidad femenina, cuyas sentencias se resolvían con bastante lenidad.

En ese contexto, previniendo el contagio de enfermedades venéreas que las milicias de los fuertes, pudieran contraer, el Dictador prohibió el ingreso de mujeres de vida pública a tales sitios. En 1825, el comandante de la plaza de Concepción informó al gobierno que unas mujeres oriundas de la ciudad de Corrientes, Cándida Rosa Ojeda y su amiga Luisa, residentes en la citada localidad "se hallaban enfermas de mala enfermedad", además ambas eran "de dudosa ética". El doctor Francia, al conocer la situación, ordenó de inmediato el desalojo de Concepción de aquellas mujeres "por los graves males que podrían causar a los

${ }^{38}$ Potthast-Jutkeit, Bárbara. 1996 Paraíso... opus cit. pp.74/75

${ }^{39}$ ANA. S.J.C. Vol. 1520. Año 1819. 
soldados"40. Por consiguiente, revisados los dictámenes de los jueces, cabe suponer que tanto la prostitución como el adulterio se penalizaban con destierros, amonestaciones, retiros a casas de familias respetables, y no precisamente con encierros en la cárcel pública.

Si bien, el sistema penitenciario en la etapa dictatorial fue bastante severo en los casos de traición a la patria, conspiraciones, robos y asesinatos, no es de extrañar que por la misma época, en otras ciudades americanas consideraran similares sanciones a las impuestas en el Paraguay. Registros de varios penales demuestran que tanto el azote y otro tipo de torturas corporales quedaban al arbitrio de los guardianes y que generalmente estos se valían de tales correctivos como forma de conservar la disciplina en las prisiones. Además, los presos no podían mantener comunicación de ninguna clase con familiares o 37 amigos, ni escribir o recibir correspondencia, salvo casos especiales, que podían ser visitados por inspectores, ministros de culto, médicos y empleados de la prisión ${ }^{41}$. Semejantes represiones también se ejecutaban en cárceles de mujeres, en donde las acusadas de adulterio, prostitución o hechicería recibían azotes, castigos físicos y sicológicos por tales delitos. En Buenos Aires, por ese tiempo, a más de las torturas, grilletes y cepos, se penaban con los fusilamientos en casos de homicidios o de traición a la patria $^{42}$.

\footnotetext{
${ }^{40}$ ANA. S.H. Cuaderno de Instancias anotadas por el Juez de Paz. 28-II-1825

${ }^{41}$ Herboso, Francisco J. 1892. Estudios Penitenciarios. Santiago de Chile, citado por Viola, Alfredo. 1983 en Las cárceles, opus cit. p. 140.

42 Wilde, José Antonio. 1944. Buenos Aires desde setenta años atrás. Buenos Aires. Espasa Calpe, pp.30/32.
} 


\section{Gobierno de los López (1844-1870)}

Durante el gobierno de los cónsules Mariano Roque Alonso y Carlos Antonio López (1841-1844), se creó la Policía de la Capital y se estableció un Estatuto Provisorio de Administración de Justicia, que contemplaba las penas y castigos para los delincuentes y la ubicación de los diversos reclusorios del país. A más de la cárcel pública situada en Asunción, las demás penitenciarias se hallaban ubicadas en los edificios de los juzgados del interior. Sin embargo, no se menciona que el nuevo gobierno haya destinado un presidio exclusivo para mujeres. Ellas cumplían sus condenas en las mismas instalaciones que los varones, aunque separadas y encerradas en calabozos con la llave echada, pero si las penas eran por casos leves eran recluidas en sus casas. No obstante, cabe mencionar que por el citado Estatuto quedaban derogadas las penas de tormento y la confiscación de bienes, no así los castigos físicos. Tuvieron vigencia en esta etapa, al igual que en la anterior, los azotes, el cepo y grilletes. A los soldados desertores o que se rebelaban se imponía el castigo de "carrera de palos". Por diversos delitos, las mujeres, igualmente, sufrieron castigos corporales y los grillos ${ }^{43}$.

Cuando don Carlos A. López asumió la presidencia, en 1844, hubo intenciones de acomodar el país a las normas europeas, no solo en lo material, sino también en lo administrativo, cultural y religioso. En atención a este último aspecto, el gobierno trató que la iglesia paraguaya reordenase la moral teológicamente abandonada y, a ese efecto, se fijaron las formalidades relacionadas con el

\footnotetext{
${ }^{43}$ Viola, Alfredo. 2004. Cárceles y otras penas. Época de Carlos Antonio López. Asunción. Servilibro, p.43.
} 
matrimonio que los sacerdotes habían interpretado más de acuerdo a sus propios juicios que con lo estipulado en el Derecho Canónico. Sin embargo, las reglamentaciones religiosas o administrativas que velaban por la moral ciudadana no impidieron proseguir con la práctica de uniones libres. Los jueces del interior debían informar al gobierno de esta situación, so pena carcelaria para el hombre, y grilletes para la mujer hasta tanto llegaran a legalizar su unión.

Las transgresiones más comunes penadas en este período fueron el abigeato, propaganda contra el gobierno, juego de naipes, robos, hurtos, deserción militar, amancebamiento, intento de suicidio, homicidios, rapto, violaciones, sodomía, estupro, que generalmente perpetraban los hombres, en tanto los delitos más comunes cometidos por mujeres fueron mendicidad, adulterio, prostitución, aborto, infanticidio, desordenes en la vía pública por ebriedad, comentarios injuriosos y desacato contra las autoridades. Algunos de ellos fueron registrados en diversos documentos de la época.

Es de advertir que, los presos eran obligados a trabajar en las obras públicas o eran confinados a poblar nuevos asentamientos. Con respecto a las penas, un inventario de la época registra la existencia de 156 grillos, 22 de ellos ocupados; 154 grilletes, 68, en uso; 6 cadenas de acogollar y 3 cepos en los cuales se aseguraba la garganta o los pies del prisionero. Una pala de hierro para hacer los hoyos e instalar la horca en la plaza pública; 5 azotes de piel de vaca y un cabestro, una picota de madera donde ataban al o a la 
prisionera para su lapidación; 2 horcones y una viga que servían de horca para los sentenciados a muerte ${ }^{44}$.

Es probable que, por la multivariedad de delitos, la cárcel pública no tuviese espacio para albergar a tantos reos. Así en 1849, el presidente López ordenó que ninguna mujer con penas de simple arresto fuese recluida en el citado penal, "pudiendo el juez remitirla a casas de respeto", es decir, a un hogar de un vecino de comprobada moral pública, hasta tanto se construya una prisión para las delincuentes ${ }^{45}$.

Hacia 1851, se concluyó la construcción de una nueva cárcel, erigida a metros de la Catedral de Asunción, cercana a los edificios públicos de la ciudad. El terreno de la misma fue adquirido de doña María Isabel Álvarez y constaba de unas cinco celdas para los hombres y una dependencia espaciosa para las mujeres criminales, ladronas, prostitutas y adúlteras. Los documentos no mencionan a las que mantenían uniones libres, es decir, aquellas que incurrían en concubinato, pese a las disposiciones del gobierno en su intención de erradicar esta ilegalidad. Un decreto fechado en 1846, instaba a los jueces, celadores, sargentos y otras autoridades que persiguiesen a los "amancebados, suprimiendo así esta mala costumbre, amonestándoles que en la primera reincidencia serían remitidos a la capital"46

Referencias sobre prostitución la hallamos en la sanción impuesta a dos mujeres conocidas, tanto por ejercer tal profesión, como ladronas de sus clientes. A la parda Valentina Dolores Cáceres, por su "conducta irregular pública y ratera incorregible", y su amiga Encarnación Fabio, "por causas semejantes", el juez solicitaba al gobierno su

44 Durán, Margarita. La cárcel pública... opus cit.

${ }^{45}$ ANA. S.H. Vol. 287. № 4. 25-VIII-1849.

${ }^{46}$ Viola, Alfredo. 2004. Cárceles y otras penas... opus cit., p.142. 
expulsión de Asunción, no sin antes recibir los treinta azotes estipulados en la Ley por su "mal comportamiento" 47. Similares castigos recibían las mujeres que cometían adulterio. En 1843, en el pueblo de Santiago, Nicolasa Arapague, fue sorprendida infraganti con su amante en su propia casa, por el marido. Este, ofuscado por la infidelidad de su esposa, en ese mismo acto mató al rival. El juez comisionado a esa comunidad ordenó que se "apliquen ochenta azotes al autor del crimen y a la mujer cuarenta", pero ambos no fueron a la cárcel porque la Ley justificaba al esposo deshonrado y la mujer porque las autoridades pretendían que ella enmendara su conducta de infidelidad si regresaba con su cónyuge ${ }^{48}$.

Habitualmente, los delitos de adulterio se penalizaban de acuerdo con las denuncias presentadas por el juez comisionado, por el esposo agraviado, por la mujer ofendida 41 o por terceros, y las sentencias variaban de acuerdo con los casos. Un expediente de 1850 señala que Rosa Antonia Vera y Bernardo Arrúa fueron derivados a la cárcel pública por las acusaciones de vecinos sobre las relaciones ilícitas que ambos mantenían con total desvergüenza, mientras el esposo, Francisco Garrido, servía como militar en el norte del país. Este, notificado de la situación, solicitó al gobierno la libertad de su esposa, a "condición de que ella se sujete, lo respete y guarde fidelidad en adelante". El juez en consideración al esposo, "que tiene la piedad de perdonar a la adúltera", concedió la petición. En tanto, el amante de la cárcel fue trasladado al lejano fuerte de Apatuyá a cumplir su pena con trabajos forzados ${ }^{49}$

\footnotetext{
${ }^{47}$ ANA. S.H. Vol. 287. № 4. 8-IX-1949.

${ }^{48}$ ANA. S.J.C. Vol. 1047, № 5, 7-I-1843.

${ }^{49}$ ANA. S.J.C. Vol. 26, № 1, 21-V-1859.
} 
Con respecto a los casos de aborto verificados en este período, fueron múltiples, así como los de infanticidio, cometidos frecuentemente por mujeres del servicio doméstico, las vendedoras del mercado de abasto, prostitutas e indígenas de los pueblos de indios. Si las señoras de las clases más altas incurrieron también en tales delitos, como es de esperar, estos no fueron documentados. Las sentencias para aquellas eran bastante severas. Primero recibían unos cuarenta o cincuenta azotes y luego eran remitidas a las estancias del Estado a trabajar por diez o más años ${ }^{50}$.

Algunas mujeres no tuvieron la suerte de ser confinadas o recibir castigos corporales y luego ser liberadas, otras debieron cumplir largos años de condena carcelaria 0 , a veces, morir en prisión, tal el caso de María Luisa Cáceres, quien en 1818, juntamente con su amante, Ignacio Chaves asesinó a su esposo y ambos fueron encarcelados de por vida. Ella falleció en 1841 y, por orden del nuevo gobierno, el reo fue destinado a trabajar en las obras públicas ${ }^{51}$.

En 1862, falleció don Carlos Antonio López y le sucedió su hijo, Francisco Solano López. Dos años más tarde, el Paraguay entró en guerra, primero, con el Brasil, y luego con la Argentina y el Uruguay. En ese contexto, el Congreso paraguayo confirió al nuevo mandatario el grado de Mariscal, para dirigir al ejército nacional, iniciándose así la trágica Guerra contra la Triple Alianza. Tras extensos periodos de combates, con enormes pérdidas humanas y materiales, para los cuatro ejércitos beligerantes, el conflicto prosiguió sin detener su marcha, y no solo las milicias, sino

\footnotetext{
${ }^{50}$ ANA. S.H. Vol. 315. № 31. 30-VI-1855. ANA. J.C.Vol.26 №36. 15-VI-1857.

${ }^{51}$ ANA. S.J.C. Vol. 35, № 52. 27-XII-1841.
} 
también la población civil paraguaya, debieron soportar las derrotas bélicas en su propio territorio.

A más de sufrir los desastres propios de la contienda, las condiciones de vida se presentaban cada vez más inestables y precarias por la escasez de abastecimiento y por las constantes movilizaciones, en las que no solo se reclutaban a hombres, sino también a adolescentes y hasta niños; razón por la que empezó a menguar vertiginosamente la convicción de una victoria paraguaya y la adhesión al mariscal-presidente. Desde fines de 1867, a medida que se acrecentaba la incertidumbre sobre la dirección de la guerra, aumentaba la represión política, situación reflejada en los informes de los jueces de paz, que ahora se referían casi exclusivamente a procesos políticos. En ese escenario de acontecimientos, el número de delincuentes femeninas era tres veces mayor que el de masculinos, por consiguiente, 43 eran las mujeres y no tanto los hombres quienes expresaban duras críticas por la "causa patriótica". Ante esta circunstancia, cabe presumir que tanto las madres, esposas, hermanas e hijas de los soldados combatientes, al mismo tiempo que derramaban lágrimas por el familiar que iba a la guerra, declaraban su oposición al gobierno ${ }^{52}$.

En febrero de 1868, Asunción fue evacuada por la proximidad del enemigo invasor, y las mujeres de todas las condiciones sociales fueron impelidas a seguir a las tropas combatientes, inclusive aquellas que debían cumplir condenas carcelarias o en las estancias del Estado también se sumaron al ineludible éxodo. Para muchas, esta expedición resultó bastante penosa por las dificultades de tener que trasportar sus escasos enseres por las sinuosas

52 Potthast-Jutkeit, Bárbara. 1996. Paraíso...opus cit., pp. 274/276. 
sendas cordilleranas. Se iniciaba, así, un verdadero vía crucis de la sociedad paraguaya.

Al principio, en obediencia a las disposiciones del gobierno, las mujeres se establecieron en localidades cercanas a la capital o fijaron sus residencias en los campos propicios para el cultivo, de ahí su denominación de residentas, pero cuando el ejército inició su retirada hacia el norte del país, se vieron en la necesidad de cumplir con apremiantes medidas como el abandono de sus sitios originarios o de las poblaciones a donde, en un inicio, le fueran asignadas.

En ese devenir, se descubrió una conspiración contra el mariscal-presidente y varias personas que otrora ocuparan puestos relevantes en el gobierno fueron arrestadas y condenadas a muerte, entre ellas, el ministro de Relaciones Exteriores, el hermano y los cuñados de Solano López y otras relevantes figuras de la sociedad. Lo característico de estos arrestos consistió en que no se limitaban a los individuos implicados, sino también a los demás familiares del presunto conspirador, no respetando sexo ni edad. Posteriormente, las represiones se extendieron a las filas del ejército, entre los campesinos del interior y a gran parte de los extranjeros y sus esposas, llegados al país antes de la guerra. Las mujeres, cuyos parientes o amigos estuvieron involucrados en el complot, fueron denominadas traidoras y también, se las sentenció a muerte. Entre los meses de junio y diciembre de 1868, se ajusticiaron a 398 personas de ambos sexos.

A unas 3.000 traidoras que no fueron ejecutadas, después de pasar todo tipo de vejaciones, se las destinó a remotos sitios, de ahí el nombre de destinadas con que posteriormente fueron conocidas. La orden de partida fue cumplida el 15 de enero de 1869. Cada grupo iba 
acompañado de un oficial, de una sargenta y de cinco muchachos, armados con pequeñas lanzas. Muchas de las destinadas, luego de soportar dolorosos sufrimientos, perecieron en los campos de Yhú, Curuguaty, Ygatimí y Espadín ${ }^{53}$. De este último sitio las, sobrevivientes fueron liberadas por las tropas brasileñas, el 25 de diciembre de $1869^{54}$.

\section{La post-guerra}

Mientras el ejército al mando de Solano López continuaba la marcha hacia el norte del territorio paraguayo, los aliados se dirigían a la capital, la que se hallaba totalmente indefensa. El $1^{\circ}$ de enero de 1869, las fuerzas enemigas hicieron su entrada en Asunción, y la ciudad vacía quedó a merced de los invasores que no escatimaron, en saquearla. La guerra culminó el 1ㅇ de marzo de 1870, con la muerte del mariscal Solano López y con la devastación del país.

Pese al despojo a que fue sometida la capital y a los desacuerdos surgidos entre los vencedores, Asunción y las demás localidades del interior fueron repoblándose paulatinamente por personas de diversos orígenes y procedencias, especialmente por un gran porcentaje de mujeres y niños, quienes recorrían las arenosas calles en busca de sustento y alojamiento ${ }^{55}$.

La tarea de reconstrucción nacional presentó una serie de dificultades, no sólo porque aún estaba vivo el recuerdo vivido durante los cinco años de tragedia, sino también por

\footnotetext{
${ }^{53}$ Estos dos últimos sitios hoy pertenecen al Brasil.

${ }^{54}$ Monte de López Moreira, Mary. 2014. História del Paraguay. Asunción. Servilibro, pp.230/231.

${ }^{55}$ Ibídem, pp. 240.
} 
las inmensas pérdidas, en todos los órdenes, ocasionadas por la guerra. Luego de la destrucción material y demográfica, sobrevino también -como era de esperarse- la desmoralización y la confusión de la diezmada población paraguaya. La búsqueda de diferentes patrones de supervivencia, de nuevas formas de enfrentar el día a día, de divertirse, de producir y reproducir, no fue tarea fácil ni exenta de serias complicaciones. Los periódicos de la época registran una cantidad importante de suicidios, trastornos psíquicos, aumento de violencia y de marginalidad, particularmente entre las mujeres.

Muchas de ellas, ebrias, provocaban alborotos, disturbios callejeros, hurtos casi siempre con consecuencias fatales. La proliferación de ladronas presentaba un inusitado interés a la prensa, agigantando sus transgresiones y creando al mismo tiempo, verdaderos mitos, sobre la delincuencia femenina.

En 1876, el periódico La Reforma noticiaba que la conocida ladrona, que durante la guerra había estado presa y engrillada en el campamento de Humaitá, y de la cual escapó, ahora había sido sorprendida robando en casa de una distinguida dama asuncena. La policía la capturó y fue enviada a la cárcel pública. Días más tarde, el mismo medio publicaba que "la famosa ladrona y célebre escaladora de murallas”, había burlado la vigilancia de los guardias y logró fugarse del reclusorio, trepando la alta pared y pasando al patio de la casa contigua donde vivía el jefe de la policía capitalina y en cuyos corredores se hallaban varios centinelas. La descripción de la mujer era la siguiente: 
"estatura colosal, corpulenta, de color negro y de fisonomía humilde"; se encontraba con paradero desconocido ${ }^{56}$.

Valentina López, conocida como Valé, fue otra ladrona muy popular en esta época, con varias entradas a la cárcel, intentos de fugas y reincidencias en sus actos delictivos. Una de las formas más comunes de robo, cometidos por mujeres, era ingresar a las casas por medio del empleo en el servicio doméstico. Una vez que sus patrones se hallaban ausentes o imposibilitados por alguna enfermedad, estas aprovechaban para desvalijar la propiedad ajena ${ }^{57}$. Era una forma de supervivencia en un escenario desolador, en donde gran parte de los hombres empleaba su tiempo en disputas por el poder político, sin resolver los problemas de fondo de una sociedad que emergía de las cenizas y que luchaba por conservar su identidad nacional.

47 No obstante, un número considerable de la población femenina no incurrió en tales delitos, por el contrario, se dedicó férreamente a la reconstrucción económica del país. Fueron las mujeres de todas las condiciones sociales quienes se dedicaron a las tareas agropecuarias, al comercio y a la industria. Para comercializar sus productos en los mercados, viajaban de una localidad a otra, comprando y vendiendo; abasteciendo de esta manera a las villas, pueblos y ciudades. Trabajaban como estibadoras en los puertos del país e, igualmente, volvieron a incrementar las industrias caseras, muy corrientes, durante la dictadura francista, entre ellas el tabaco, miel, dulces, tejidos, etc. ${ }^{58}$.

\footnotetext{
${ }^{56}$ Ribeiro Da Silva, Alberto Moby.2010. La noche de las Kyguá Verá. La mujer y la reconstrucción de la identidad nacional en la posguerra de la Triple Alianza. Asunción. Intercontinental Editora, p. 287.

57 lbídem, p. 289.

${ }^{58}$ Monte de López Moreira, Mary. 2014. Historia del Paraguay...opus cit., p. 241.
} 
En este período, aparecen en los estrados judiciales nuevos procesos. De acuerdo con las nuevas disposiciones, ya no se penalizaban las uniones libres - no así el adulterio- $y$, del mismo modo, fueron proscritos los azotes, las torturas y demás castigos físicos. Por ley del 21 de julio de 1880, se adoptó el Código Penal Argentino, que de inmediato entró en vigencia. Sin embargo, no mermaron la criminalidad, robos domiciliarios y callejeros, estupros, violaciones, abortos e infanticidios ${ }^{59}$.

Por aumento de delitos, la cárcel pública se hallaba abarrotada de delincuentes, hacinados en pequeñas celdas en medio de la insalubridad y promiscuidad. Allí convivían asesinos, prostitutas, insanas mentales, ladrones, rateras y ebrios; situación que obligó a las autoridades policiales despejar en cierta medida, el hacinamiento humano de aquella prisión, convertida en un lugar de depósito de personas. Con ese propósito, las autoridades enviaron una cantidad considerables de presos y presas a un reclusorio en la localidad de Villa Hayes ${ }^{60}$. En realidad, se trataba de un destacamento militar en cuyos alrededores se erigían "unos ranchos inmundos que a la sola vista impresiona tristemente, al considerar que en ella pasan sus días seres humanos, privados hasta de aire puro y bajo una atmosfera deletérea e insana", informaba un periódico de la época ${ }^{61}$. En esa oportunidad, unas siete mujeres y varios hombres fueron remitidos a dicho presidio. Eran ellas Juliana Aranda, Valentina Martínez, Concepción Patiño, De Jesús Rolón, María Mereles, Martina González y Josefa A. Frutos, por

${ }^{59}$ Acosta, Gustavo. 2019. Posguerra contra la Triple Alianza. Aspectos sociales (1869-1904). Asunción. Servilibro, pp. 209/243.

${ }^{60} \mathrm{La}$ localidad de Villa Hayes se encuentra al otro lado del Río Paraguay, en la Región Occidental o Chaco casi frente a la capital.

${ }^{61}$ La Democracia. Asunción. 21-V-1892. 
rateras. Mientras que, junto a seis hombres, se mencionan a Carmen Recalde y Agustina Ortigoza, todos arrestados por anarquistas, y trasladados a la dicha villa ${ }^{62}$. Se desconoce si las citadas mujeres militaban en el anarquismo 0 simplemente eran amigas o parejas de los aprehendidos.

En 1887, fueron fundados los dos primeros partidos políticos del Paraguay: El Centro Democrático, más tarde Partido Liberal, y la Asociación Nacional Republicana, ambos bajo la égida del liberalismo. Al primero se lo identificaba por el color azul y al otro, por el rojo. Sus adherentes usaban estos colores distintivos en pañuelos, camisas, vestidos, mantos, etc. No solo hombres, sino también las mujeres contendían acaloradamente por defender sus banderías, de ahí que los agentes del orden público tuvieran que actuar siempre con todo rigor y más aún si luego de violentas discusiones, se perpetraban asesinatos.

La prensa daba cuenta de cómo el sectarismo político había llegado a introducirse de lleno en gran parte de la sociedad. Las constantes controversias entre mujeres sobre el tema generalmente, se dirimían en la vía pública, en el mercado central, en los bares o a la salida de los servicios religiosos. Un periódico comenta, de manera jocosa, la disputa entre Clara Rojas, adherente al Partido Liberal, y otra mujer que se hallaba participando de las fiestas en honor a San Francisco. Terminada la celebración, la Rojas se lanzó contra su oponente, hiriéndola de varias puñaladas, por el solo hecho de vestir, aquella, una prenda con el color distintivo de los republicanos ${ }^{63}$. Días más tarde, se informaba cómo la joven Trinidad Bogarín fue atacada por varias mujeres por haberse manifestado contra la

\footnotetext{
${ }^{62}$ La Democracia. Asunción. 24-V-1892, p. 1

${ }^{63}$ El Paraguayo. Asunción, 16 de octubre de 1887, p. 2
} 
Asociación Nacional Republicana ${ }^{64}$.

Antes de finalizar el siglo XIX, la cárcel pública se hallaba colmada de presos, por distintos motivos delincuenciales, siendo los crímenes políticos los primeros en la lista. Las tres pequeñas dependencias destinadas a mujeres ya no daban cabida para albergar a más detenidas. Esta situación se fue acrecentando con el transcurrir de los años.

\section{El siglo XX}

Uno de los esparcimientos más originales de la sociedad asuncena era el paseo efectuado hasta el Recreo Villa, perteneciente a don Antonio Villa, adyacente al arroyo Mburicaó, sitio ubicado en las afueras de la ciudad. Para llegar al mismo, las familias viajaban en los tranvías de tracción a sangre. Los pasajeros abordaban el simpático vehículo en el centro capitalino. Después de unas dos horas de viaje con varias escalas, se llegaba a la Recoleta, zona cercana al cementerio del mismo nombre, y allí descendían los pasajeros e ingresaban al parque, que contaba con un restaurant, heladería y chopería ${ }^{65}$.

Con el transcurrir del tiempo, el Recreo fue perdiendo interés, debido a otras diversiones introducidas en el país en los primeros años del siglo XX, y el predio fue adquirido por un consorcio de varias personas, entre ellas el doctor Eusebio Ayala ${ }^{66}$. En 1917, el Jefe de Policía, el señor José Manuel Balteiro, se interesó en comprar la finca conocida

${ }^{64}$ El Paraguayo. Asunción, 25 de octubre de 1887, p. 3

${ }^{65}$ Entrevista al periodista e historiador Verón, Luis. 24-II- 2016.

${ }^{66}$ El doctor Eusebio Ayala fue presidente provisional en 1922 y constitucional de1932 a 1936. 
como Villa Cué67 y adecuar los aposentos existentes para convertirlo en un hogar penitenciario exclusivo de mujeres. El local, alejado de la ciudad -en ese tiempo- parecía ser ideal, ya que en la cárcel pública no había lugar para más internas. Con ese objetivo, solicitó al gobierno del presidente Manuel Franco la adquisición de la citada propiedad, transacción realizada en noviembre de ese año, por la suma de 210.000 pesos fuertes de curso legal ${ }^{68}$.

De inmediato se iniciaron las obras de la nueva correccional de mujeres, y para custodiar a las internas, el propio Jefe de Policía, José Balteiro, solicitó a la madre superiora de la Congregación de la Providencia la colaboración de las Hermanas de la Congregación de Nuestra Señora de la Caridad de Buen Pastor de Buenos Aires. En octubre de 1918, con la intermediación de las Hermanas Vicentinas y del Monseñor Juan Sinforiano Bogarín, llegaron al país las primeras religiosas, quienes se ocuparían de dirigir dicho reclusorio.

En su mensaje anual ante el Congreso, en abril de 1920, el presidente Franco informaba que "la habilitación de la Cárcel de Mujeres y correccional de Menores, se ha retardado debido a las dificultades que han tenido que salvarse paulatinamente, pero en breve será librada al servicio que se la destina en condiciones de satisfacer las exigencias del régimen moderno a que se someterá la institución"69.

Para mediados de 1921, recién quedaron concluidas las obras de construcción de la Casa del Buen Pastor. Sin

\footnotetext{
${ }^{67}$ Cué: voz guaraní que significa antiguo, viejo. Es decir Antigua Villa

${ }^{68}$ Decreto Ley № 7078. 10-XI-1917.

${ }^{69}$ Mensaje al Congreso Nacional de presidente Manuel Franco. 1ํ de abril de 1920.

El Estado General de la Nación durante los Gobiernos Liberales. 1987. Vol. I. Asunción. Archivo del Liberalismo, p.362.
} 
embargo, desde 1919, con la asistencia de las religiosas se fueron incorporando gradualmente varias detenidas. En breve tiempo, las autoridades judiciales pudieron comprobar los cambios operados en las internas. La intención de las autoridades se centraba en que la nueva cárcel de mujeres y correccional de menores sirviera de escuela de moralidad y trabajo para las reclusas $y$, si bien la capacidad del edificio era un tanto reducida, se trataba de evitar toda posibilidad de contacto entre las penadas y las menores de edad, a quienes se pretendía educar para luego reinsertarlas a la sociedad $^{70}$. Es así como, después de tres siglos y medio, se logró cumplir con lo estipulado en las vetustas leyes hispanas que establecían la necesidad de construir penales para varones y casas de encierro para mujeres, separadas de aquellos ${ }^{71}$.

Con el transcurrir de los años, se erigieron instituciones y se promulgaron leyes con el objetivo de mejorar el sistema penitenciario paraguayo. Es así como, en 1948, se creó el Ministerio de Justicia y Trabajo, entidad a la que correspondió la organización penitenciaria del país. En 1956, se instauró la Dirección de Institutos Penales, y de ella empezaron a depender la Penitenciaria Nacional para hombres y la Casa del Buen Pastor. Con posterioridad, se promulgó la Ley $210 / 70$ con normas -hoy ya obsoletas- que atentan contra los derechos fundamentales y que ameritan un estudio más moderno sobre la legislación carcelaria.

La Casa del Buen Pastor fue creciendo con la llegada de más internas, hecho que determinó la construcción y adaptación de más celdas. Todas estas ampliaciones fueron

${ }^{70}$ Mensaje al Congreso Nacional de presidente Manuel Gondra. 1 de abril de 1921. El Estado General...opus cit., p.437.

${ }^{71}$ Recopilación de Leyes de los Reynos de las Indias. Libro VII. Leyes I, II, III. Titulo 6. Tomo Segundo...opus cit. 
ejecutadas con la ayuda de la comunidad y la paciente labor de las religiosas. De esta manera. gracias a su diligente tarea, se obtuvo la personería jurídica de la institución ${ }^{72}$. En cuanto a los delitos perpetrados por mujeres en esta etapa, la casa no solo albergó a mujeres que delinquían en robos, abortos 0 asesinatos, sino que en el decurso de los gobiernos dictatoriales de Higinio Morínigo (1940-1948) y Alfredo Stroessner (1954-1989) fueron recluidas muchas opositoras a dichos regímenes que manifestaban públicamente sus opiniones. Generalmente, estas mujeres pertenecían a partidos o movimientos de izquierda. Así, varias de ellas, sin procesos, permanecieron largas temporadas en cierta comisaría denominada la Técnica, donde también fueron torturadas y ultrajadas.

Desde los años de 1950 en adelante, las religiosas coadyuvaron positivamente con el financiamiento del 53 presidio, no solo para cubrir los gastos del mismo, sino también para que las reclusas tuviesen un incentivo económico, mediante la confección de trabajos manuales, como el bordado para ajuares de novias, que se vendían a un buen precio. Otras, se dedicaron al lavado y planchado de ropas de personas de afuera. Con la retirada de las hermanas de la Caridad del penal, en 1985, ese apoyo fue decreciendo paulatinamente.

A partir de la década de los 80 , otro tipo de ilegalidad, el tráfico de estupefacientes, se fue sumando a los delitos ya conocidos. Innumerables mujeres fueron encarceladas por tenencia, consumo o comercio de drogas no autorizadas. Además, en este período empezaron a habilitarse otros reclusorios regionales en varias ciudades importantes del país.

72 Decreto Ley № 1607. Año 1963. 


\section{Desafíos actuales}

La Casa del Buen Pastor, tras el retiro de las religiosas, es custodiada por guardiacárceles, tanto varones como mujeres. El predio solo puede albergar a un poco más de 200 reclusas; sin embargo, desde hace tiempo ha superado esa capacidad, debido al ingreso de mujeres detenidas por la distribución de drogas, en especial del crack, realidad que ha incrementado en los últimos años la población del penal. En la actualidad, casi a diario ingresan mujeres $y$, en algunos casos, entran varias personas pertenecientes a una misma familia que incurren en el mismo delito. Entre ellas, adolescentes, jóvenes y hasta mujeres de la tercera edad, amas de casa, vinculadas al tráfico de estupefacientes. Un ejemplo de lo expuesto, es el caso de la esposa, la hija, la nuera y la suegra del narcotraficante Javier Rotela, conocido como el "zar del crack". Circunstancia que ha obligado a las autoridades carcelarias a aumentar el número de internas en cada celda. A comienzos del presente siglo, en cada aposento se instalaban a dos detenidas. En la actualidad esa cantidad aumentó a cuatro y a veces más ${ }^{73}$.

En el año 2015, por la excesiva cantidad de reclusas, el Ministerio de Justicia dispuso el cierre temporal del penal del Buen Pastor, en atención a lo dispuesto por la Ley, que "el número de internos en cada penitenciaria no podrá superar su capacidad máxima certificada, a fin de asegurar la adecuada custodia y tratamiento delo interno" ${ }^{\text {"4 }}$. No obstante, en poco tiempo, el reclusorio de nuevo abrió sus puertas porque muchas detenidas consiguieron su libertad.

${ }^{73}$ Entrevista a la Directora de la Casa del Buen Pastor, Elga Escobar. Diario ABC Color. 19-IX.2012, p. 48.

${ }^{74}$ Ley № 5162/14. Código de Ejecución Penal de la República del Paraguay. Artículo 79 
En el presente, tras descubrirse la intención de introducir armas, inclusive una granada y estupefacientes en toallas higiénicas y en cajas de leche en polvo, hallados en el muro perimetral que linda con dicha cárcel de mujeres, la ministra de Justicia Cecilia Pérez, comunicó que, luego de varias pesquisas, se localizó a la destinataria de los mencionados elementos, quien de inmediato fue trasladada a otro sitio. Además, la funcionaria del Estado informó que existe un gran déficit de espacio físico en el Buen Pastor, y que el $60 \%$ de mujeres detenidas son por narcotráfico, y el resto corresponde a reclusiones por hurto, robos agravados, estafas y asesinatos ${ }^{75}$.

Otras internas y que no se hallan penadas por los delitos anteriormente señalados, son las integrantes de la organización criminal conocida como Ejército del Pueblo Paraguayo (EPP), cuyas acciones están relacionadas con secuestros, extorciones y atentados contra la policía y contra los hacendados de la región norte del país. En la actualidad, tres mujeres están presas en un pabellón de máxima seguridad, junto con las condenadas por homicidios.

Las más revoltosas, aquellas que presentan un comportamiento difícil, están aisladas en otro sector, en celdas no muy higiénicas. En tanto, en los demás pabellones, con camas marineras, se hallan las reclusas que manifiestan una mejor conducta. Ellas son las artesanas y las obreras que trabajan para comerciar sus manufacturas. A pesar de que la casa cuenta con un comedor y cocineras, algunas internas preparan ciertos platos que luego venden a sus compañeras.

${ }^{75}$ Entrevista a la ministra de Justicia, Cecilia Pérez. Programa televisivo La Lupa. 18-VII-2021. 
A partir del 2010, en la Casa del Buen Pastor, se implementó el programa "Amanecer", que acoge a los niños recién nacidos, hasta los tres años, de las recluidas que ingresaron embarazadas y dieron a luz en el penal o de aquellas que al momento de su detención tenían hijos pequeños. Al pasar los tres años, los niños deben abandonar el penal, y son entregados a familiares cercanos. El citado programa incluye, también, asistencia a las embarazadas $^{76}$.

Otro proyecto canalizado por el citado correccional es el programa "Acceso de las mujeres privadas de libertad al servicio de mediación". Con esta iniciativa, se pretende canalizar los constantes reclamos de las internas con relación a la situación de sus niños, quienes también sufren las consecuencias de su reclusión. El plan contempla, asimismo, la mediación como herramienta de resolución alternativa de conflictos, problemas muy comunes en las prisiones.

En Ciudad del Este, localidad fronteriza con el Brasil, se encuentra otra penitenciaria de mujeres, Juana María de Lara $^{77}$, en donde se inauguró el proyecto de Cárcel Industrial de Mujeres, mediante una alianza Público-Privada entre el Ministerio de Justicia y la multinacional Fujikura, con los estándares de calidad e infraestructura internacionales. El citado emprendimiento es un modelo de reinserción a través del cual las mujeres privadas de su libertad, tienen la oportunidad de capacitarse, generar ingresos, sustentar a sus familias desde la cárcel $y$, en régimen de libertad, tendrán la facilidad de ingresar a la mencionada empresa. EI

\footnotetext{
${ }^{76}$ Entrevista a la Directora de la Casa del Buen Pastor... opus cit.

77 Juana María de Lara, fue una de las mujeres que trabajó de cerca con los próceres de la Independencia Nacional en la gesta revolucionarias de 1811.
} 
requisito fundamental para formar parte del proyecto es la disciplina, la eficacia y la perseverancia, solo así se obtendrá el éxito en el citado programa ${ }^{78}$.

Considerando que la mayor parte de las internas recluidas en las penitenciarías, tanto regionales como de la capital, proviene de hogares pobres y en consecuencia no ha tenido la oportunidad de estudiar o concluir sus estudios, el Ministerio de Educación ha implementado en siete correccionales del país varios programas, entre ellos: alfabetización, escuela primaria y secundaria. Además, gracias a un convenio interinstitucional entre el Ministerio de Justicia y una universidad privada de Asunción, algunas reclusas del Buen Pastor serán beneficiadas con una educación universitaria dentro de la cárcel. Así, varias mujeres están cursando la carrera de Derecho y Ciencias Sociales y la de Psicología. Igualmente, otras han 57 incursionado al campo de las artes -música, pintura, cerámica, etc.- como parte de su rehabilitación ${ }^{79}$.

Con el propósito de optimizar la situación de las internas, se ha dispuesto una actividad conjunta del Ministerio de la Mujer, a través del Departamento de Salud Integral y la Dirección de Mecanismos de Género, dependientes del Viceministerio de Igualdad y No Discriminación (VIND), el Ministerio de Justicia, a través de la Directora de la Cárcel de Mujeres del Buen Pastor y el Ministerio de Salud Pública y Bienestar Social, a través de la XI Región Sanitaria y el Instituto Nacional del Cáncer, no solo para que las reclusas reciban asistencia médica, sino también, para que su reinserción social, sea más adaptable ${ }^{80}$.

\footnotetext{
${ }^{78}$ Diario La Nación. Asunción. 15-VI-2015, p.6.

${ }^{79}$ Diario Última Hora. Asunción, 7-IX-2011

${ }^{80}$ Portal. Ministerio de la Mujer, 2019.
} 
En el presente, existen en el Paraguay diez y seis penitenciarias ubicadas en las principales ciudades del país. Entre ellas, se encuentran dos exclusivas de mujeres, dos granjas- correccionales y un reformatorio de menores. Las de mayor capacidad se sitúan en la capital como la Penitenciaria Nacional de Tacumbú, con más de 3.000 hombres y la Casa del Buen Pastor con casi 500 mujeres que pasan sus días en el citado reclusorio en espera de sus procesos y cumplimiento de condenas. Las otras cárceles regionales cuentan también con reclusorios para mujeres, pero casi todos se hallan en un mismo edificio, situación que generalmente ocasiona serias dificultades para las autoridades carcelarias pues, al encontrarse juntos los presos de ambos sexos, tanto los hombres como las mujeres se extralimitan en sus comportamientos y se pasan de un pabellón a otro. Ante las reiteradas denuncias sobre estos hechos, se ha intentado implementar políticas de prevención del delito y tratamiento al delincuente.

Por otra parte, se deben solucionar de manera urgente otros problemas propios de los penales de mujeres, como la erradicación de esquemas corruptos liderados por los guardia cárceles; el uso continuo de celadores masculinos, pese a que esta práctica se halla prohibida en la Ley 210/70, y la falta de financiamiento para alimentar a los hijos de las reclusas que viven dentro del correccional junto a sus madres. Usualmente, los que sostienen la citada dependencia son benefactores privados $u$ organizaciones sociales que palian esta carencia.

El incumplimiento de las condiciones básicas que deben existir en los reclusorios femeninos, la falta de una política criminal apropiada y la ausencia de una correcta aplicación de los principios y garantías fundamentales para las 
prevenidas y condenadas presentan en la actualidad un grave obstáculo para la rehabilitación y reinserción de mujeres delincuentes en el Paraguay.

\section{Conclusión}

El trabajo que reseña la situación penitenciaria de mujeres a través de la historia no fue una gestión fácil, pues se debieron exhumar antiguos documentos guardados en diversos repositorios y hurgar en amarillentas páginas de periódicos o en manuscritos deteriorados por el tiempo. De esta forma, se ha pretendido elaborar un capítulo casi ignoto en la historia social del Paraguay, desde la etapa inicial de la conquista hasta nuestros días, y evidenciar que la misma problemática de condenas y juicios a mujeres, registrados en los diversos períodos de gobierno, aún están vigentes en la actualidad.

A criterio de un experto en regímenes carcelarios, el sistema paraguayo se halla en un estado deplorable, al igual que el de muchos países latinoamericanos ${ }^{81}$. El problema no es reciente, pues se viene arrastrando de décadas anteriores y se fue agravando con el tiempo por la falta de prevención y aplicación de los enfoques fundamentales que hasta el presente no fueron tratados en forma exhaustiva. Por esta razón, constantemente se están violando los derechos humanos consagrados, no solo en la Carta Magna paraguaya, sino también en la Convención Americana de Derechos Humanos.

${ }^{81}$ Delmás, José. Problema carcelario y contradicciones del sistema. Diario ABC. Sección Judicial.

28-III-2016, p.12/13. 
Uno de los objetivos fundamentales del gobierno, en materia carcelaria, debería centrarse en la planificación de una política criminal, cimentada en el conjunto de medios y recursos utilizados por el Estado con miras a la prevención del delito, reducción de la criminalidad, tratamiento al privado o privada de su libertad y avance del sistema de justicia penal. Si se pretende erradicar el problema de raíz o por lo menos morigerar, se deben realizar una interrelación y cooperación más estrecha entre los diferentes poderes.

Hoy día, se puede ver el gran esfuerzo del Poder Judicial en la búsqueda de soluciones a este problema. En ese sentido, las autoridades del Ministerio de Justicia solicitaron a los congresistas acompañar los proyectos emprendidos por dicha cartera, además de la promoción de iniciativas legislativas que ayuden a descomprimir los principales centros de reclusión y la provisión de recursos económicos, a través de ampliaciones presupuestarias para construir unas cuatro penitenciarias más modernas, en atención al nuevo paradigma aplicado en algunas cárceles de Argentina y Centroamérica, convertidas hoy en aulas y talleres para los presos de ambos sexos, y fomentar así, su reinclución social.

Ante esa perspectiva coyuntural, se trata de implementar el nuevo concepto de las cárceles, sustentado por el lema "Más aulas y menos celdas". Un ejemplo de ello es el penal de mujeres, Juana María de Lara, cuyo programa de reinserción ha sido declarado de interés nacional por el Congreso paraguayo y fue expuesto por expertos de Naciones Unidas como ejemplo de Reinserción Mundial en 
el $13^{\circ}$ Congreso de la ONU contra la Droga y el Delito celebrado en la ciudad de Doha, Qatar ${ }^{82}$.

Pese a todos los programas y proyectos de reinserción de las internas de las diferentes penitenciarias del país y la lucha del Poder Judicial para mejorar el sistema de justicia, tanto en relación con la morosidad procesal, como con el problema del régimen carcelario, se necesita una urgente reforma de la legislación existente e implementar una adecuada política de justicia. Se deben buscar soluciones efectivas en un contexto de justicia social y dar respuesta a las necesidades de una población cada vez más empobrecida, en cuanto a la oportunidad laboral, sin normas discriminatorias, y la instauración de nuevas políticas sociales que redunden en beneficio de la comunidad.

\section{Referencias}

- Acosta, G. 2019. Posguerra contra la Triple Alianza. Aspectos sociales (1869-1904). Asunción. Servilibro.

- Caballero Campos, H. 2007. Los bandos del buen gobierno de la Provincia del Paraguay 1778-1811. Asunción.

- Catálogo de pasajeros a Indias. 1942. Vol. II y III. Editorial de la Gavidia. Sevilla,

- De las Heras Santos, J. L. 2016. La mujer y la moral en la legislación castellana de la Edad Moderna. www.historiaetius. Documento 30.

82 Portal Ministerio de Justicia. República del Paraguay. 2015. Secretaría Nacional de Tecnologías de la Información y de la Comunicación. 
- Gandía, E. 1932. Historia de la conquista del Río de la Plata y del Paraguay. Buenos Aires. Librería de A. García Santos.

- Herboso, F.J. 1892. Estudios Penitenciarios. Santiago de Chile,

- Machado de Chávez. El Perfecto II, p. 429. Citado por Mannarelli, María Emma. 1993. Pecados púbicos.

- Mannarelli, M.E. 1993. Pecados púbicos. La llegitimidad en Lima, siglo XVII. Lima, Editorial Flora Tristán.

- Mensaje al Congreso Nacional de presidente Manuel Franco. $1^{\circ}$ de abril de 1920. El Estado General de la Nación durante los Gobiernos Liberales. 1987. Vol. I. Asunción. Archivo del Liberalismo.

- Mensaje al Congreso Nacional de presidente Manuel Gondra. $1^{\circ}$ de abril de 1921. El Estado General. Estado General de la Nación durante los Gobiernos Liberales. 1987. Vol. I. Asunción. Archivo del Liberalismo.

- Monte de López Moreira, M. 2013. Pancha Garmendia. Asunción. El Lector.

- Monte de López Moreira, M. 2014. Historia del Paraguay. Asunción. Servilibro.

- Portal Ministerio de Justicia. República del Paraguay. 2015. Secretaría Nacional de Tecnologías de la Información y de la Comunicación.

- Potthast-Jutkeit, B. 1996. Paraíso de Mahoma o País de las Mujeres. Asunción. Instituto Cultural ParaguayoAlemán.

- Recopilación de Leyes de los Reynos de las Indias. Libro VII. Leyes I, II, III. Titulo 6. Tomo Segundo. Cuarta Impresión. Madrid, 1943. Consejo de la Hispanidad.

- Rengger, J. -Lompchamp, M. 1828. Ensayo histórico sobre la Revolución del Paraguay y el Gobierno Dictatorial del Dr. Francia. París. Imprenta de Morteau.

- Ribeiro Da Silva, A.M.2010. La noche de las Kyguá Verá. La mujer y la reconstrucción de la identidad nacional en la posguerra de la Triple Alianza. Asunción. Intercontinental Editora. 
- Rodríguez Alcalá, G. 1997. Justicia Penal de Francia. Asunción. RP Ediciones.

- Viola, A. 1983. Las cárceles en la época dictatorial. Asunción. Anuario del Instituto de Investigaciones Históricas “Dr. José Gaspar Rodríguez de Francia”. Año X. № X.

- Viola, A. 2004. Cárceles y otras penas. Época de Carlos Antonio López. Asunción. Servilibro.

- Wilde, J.A. 1944. Buenos Aires desde setenta años atrás. Buenos Aires. Espasa Calpe.

\section{Archivo Nacional del Paraguay:}

- $\quad$ ANA. SNE. Vol. 302. Fo. 21. 25-I-1545.

- ANA. Copias de Actas del Cabildo de Asunción. Vol. 11. 24-XII-1588, pp. 129/130.

- ANA. Sección Civil y Judicial. Vol. 1676. 26-VI-1584. Fos. $1-53$.

- ANA. Sección Civil y Judicial. Vol. 1853. 7-XII- 1584. Fos. 1-95.

- A.N.A.S.H. Vol. 203. №3 Fo. 7. 29-I-1807.

- ANA. Colección copias de Actas del Cabildo de Asunción. Vol. 31. 7-I-1793.

- ANA. SJC. Vol. 1670. Año 1819.

- A.N.A. S.N.E. Vol. 750. 23-X-1816.

- $\quad$ ANA. S.H. Vol. 226. 1--III-1816.

- ANA. S.J.C. Vol. 1520. Año 1819.

- $\quad$ ANA. S.H. Cuaderno de Instancias anotadas por el Juez de Paz. 28-II-1825

- $\quad$ ANA. S.B.T. P. 1501. 29-IX-1848.

- $\quad$ ANA. S.H. Vol. 287. № 4. 25-VIII-1849.

- $\quad$ ANA. S.H. Vol. 287. № 4. 8-IX-1949.

- $\quad$ ANA. S.J.C. Vol. 1047, № 5, 7-I-1843.

- $\quad$ ANA. S.J.C. Vol. 26, № 1, 21-V-1859.

- $\quad$ ANA. S.H. Vol. 315. № 31. 30-VI-1855.

- $\quad$ ANA. J.C.Vol.26 №36. 15-VI-1857.

- $\quad$ ANA. S.J.C. Vol. 35, № 52. 27-XII-1841. 


\section{Periódicos/Entrevistas:}

- La Democracia. Asunción. 21-V-1892.

- La Democracia. Asunción. 24-V-1892.

- El Paraguayo. Asunción, 16 de octubre de 1887, p. 2

- El Paraguayo. Asunción, 25 de octubre de 1887, p. 3

- Diario La Nación. Asunción. 15-VI-2015, p.6.

- Diario Última Hora. Asunción, 7-IX-2011

- Delmás, José. Problema carcelario y contradicciones del sistema. Diario ABC. Sección Judicial. 28-III-2016.

- Portal. Ministerio de la Mujer, 2019

- Durán, Margarita. La cárcel pública de Asunción (15411955). Diario ABC Color. 19-VIII-2012.

- Entrevista a la Directora de la Casa del Buen Pastor, Elga Escobar. Diario ABC Color. 19-IX.2012.

- Entrevista al periodista e historiador Luis Verón. 24-II2016. Asunción.

\section{Decretos/Leyes:}

- Decreto Ley № 7078. 10-XI-1917.

- Decreto Ley № 1607. Año 1963.

- Ley № 5162/14. Código de Ejecución Penal de la República del Paraguay. Artículo 79. 